J. W. Rijstenbil · J. W. M. Derksen · L. J. A. Gerringa

T. C. W. Poortvliet $\cdot$ A. Sandee $\cdot$ M. van den Berg

J. van Drie · J. A. Wijnholds

\title{
Oxidative stress induced by copper: defense and damage in the marine planktonic diatom Ditylum brightwellif, grown in continuous cultures with high and low zinc levels
}

Received: 16 February 1994 / Accepted: 24 March 1994

\begin{abstract}
Light-limited cultures of the planktonic diatom Ditylum brightwellii (West) Grunow were grown at $14 \%$ o salinity. Cells were subjected to oxidative stress induced by copper, in the presence of zinc. In two continuous cultures with total $\mathrm{Zn}$ levels of 40 and $140 \mathrm{n} M$, respectively, dissolved $\mathrm{Cu}$ levels were increased from 3 to $126 \mathrm{n} M$. This resulted in an increased $\mathrm{Cu}$ adsorption capacity of the cell walls, probably due to an increase of surface area and roughness. Sexual reproduction (auxospore formation) was accelerated but was considered as a non-specific stress response. $\mathrm{Cu}$-induced oxidative stress was indicated by a decrease of reduced glutathione (GSH), and a removal of superoxide anions monitored as an increasing activity of superoxide dismutase (SOD). Although $\mathrm{Zn}$ has no oxidative potential per se, cell division rates and chlorophyll $c$ contents were lower in the culture with high $\mathrm{Zn}$ levels. In both cultures, the pro-oxidant $\mathrm{Cu}$ caused a decrease of chlorophyll $a$, decreasing photosynthetic $\mathrm{O}_{2}$ evolution and cell devision rates, and a growing number of deformed and broken cells.
\end{abstract}

\section{Introduction}

Oxidative stress in aquatic organisms is a normal phenomenon, caused by a number of natural external factors (e.g. UV-B radiation), but it can be promoted by some pollutants (Stegeman et al. 1992). Many organochemicals (quinones, nitroaromatics, aromatic hydroxylamines) and transition metals (e.g. copper) are pro-oxidants, which catalyze and accelerate the formation of oxyradicals in plants

Communicated by $\mathrm{O}$. Kinne, Oldendorf/Luhe

J. W. Rijstenbil (凶) - L. J. A. Gerringa - T. C. W. Poortvliet A. Sandee - M. van den Berg - J. van Drie - J. A. Wijnhold

Netherlands Institute of Ecology, Centre for Estuarine and Coastal Ecology, Vierstraat 28, NL-4401 EA Yerseke, The Netherlands

J. W. M. Derksen - M. van den Berg

Catholic University Nijmegen, Botanical Department, Toernooiveld, 6525 ED Nijmegen, The Netherlands
(Salin 1987). Due to this oxidative potential, copper is a very toxic metal, not just because of its high affinity for thiol-sites ( $-\mathrm{SH})$ on proteins, as this is also the case for e.g. cadmium and zinc (Reed and Gadd 1990). An excess of $\mathrm{Cu}$-induced oxyradicals disturbs the pro- vs antioxidant balance and enhances lipid peroxidation (membrane disintegration, failure of osmoregulation), which shortens the lifetime of cells (De Vos and Schat 1991; Lee and Hassan 1985).

At low values, both $\mathrm{Cu}$ and $\mathrm{Zn}$ stimulate phytoplankton growth (Brand et al. 1983; Verweij et al. 1992), but a slight excess of both metals binds SH sites, while $\mathrm{Cu}$ also oxidizes -SH to disulfur (-SS-) bridges in proteinaceous biomolecules, causing a cumulative, inhibitive $\mathrm{Cu} / \mathrm{Zn}$ effect (Stauber and Florence 1987, 1990; French and Evans 1988; Rijstenbil and Poortvliet 1992). With speciation models it was calculated that for most algae, ion activities of $\mathrm{Cu}^{2+}$ limit growth below $10^{-13} \mathrm{M}$, and become sublethal above $10^{-11} M$ (Brand et al. 1986; Verweij et al. 1992). Ditylum brightwellii is a $\mathrm{Cu}$-sensitive diatom species, blooming in estuaries and coastal waters (Canterford and Canterford 1980; Rijstenbil and Wijnholds 1991; Rijstenbil et al. 1993; Rijstenbil et al. in press). At $10^{-11} \mathrm{M} \mathrm{Cu}^{2+}$, its cell division was slightly inhibited, but its growth ceased abruptly between $10^{-10.3}$ and $10^{-9.3} \mathrm{M} \mathrm{Cu}^{2+}$ (Brand et al. 1986; Gerringa et al. in press). It is expected that even at low $\mathrm{Cu}$ and $\mathrm{Zn}$ levels, $D$. brightwellii shows a poor defense against metal toxicity and suffers from oxidative damage (Rijstenbil et al. in press).

We investigated how Ditylum brightwellii was affected by increasing levels of available $\mathrm{Cu}$, which exceeded the equivalent of the ligand in the medium (Rijstenbil and Wijnholds 1991). Although $\mathrm{Zn}$ has no oxidative effect, earlier observations showed that it indirectly stimulated superoxide dismutase activity in this diatom (Rijstenbil et al. in press). For this reason, the cumulative effect of $\mathrm{Zn}$ was further investigated. In the present paper, continuous cultures were run at two different zinc levels: $40 \mathrm{n} M(\mathrm{Zn}-)$ and $140 \mathrm{n} M(\mathrm{Zn}+)$. For $121 \mathrm{~d}$ dissolved $\mathrm{Cu}$ was stepwise, but gradually increased from $\sim 3$ to $126 \mathrm{n} M$ in the medium. The data concerning external metal speciation and metal ad- 
sorption to the cell wall have been described elsewhere (Gerringa et al. in press). Here, we have examined whether or not metabolic responses of $D$. brightwellii to $\mathrm{Cu}$ were: (1) related to additional $\mathrm{Zn}$ in the medium; (2) part of its antioxidant defense; or (3) attributable to oxidative cell damage.

\section{Materials and methods}

Media and culture conditions

Artificial brackish medium was prepared as described in Rijstenbil et al. (1989). Salinity (14\%o) was measured with a WTW-LF2000CONX conductivity meter. Metals were removed from the salt solution by CHELEX-100 (Morel et al. 1979; Rijstenbil and Wijnholds 1991). Media were enriched with $200 \mu M$ nitrate, $108 \mu M$ silicate and $18 \mu M$ orthophosphate, and $56.5 \mathrm{n} M \mathrm{Na}_{3}$ EDTA was used as a metal chelator. The $\mathrm{pH}$ of the medium was 7.8 (PHM 80 Radiometer Copenhagen). Media were filter-sterilized $(0.2 \mu \mathrm{m})$. Axenic cells of the marine planktonic diatom Ditylum brightwellii (West) Grunow were grown in 6-liter glass vessels (siliconized borosilicate; Techne, Cambridge UK), at $10^{\circ} \mathrm{C}$. Cells were irradiated at a mean level of $83 \mu \mathrm{mol}$ quanta $\mathrm{m}^{-2} \mathrm{~s}^{-1}$ measured inside the culture suspension with a QSL-100 $4 \pi$-sensor (Biospherical Instruments) in a light

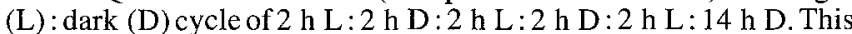
alternate photoperiodicity was designed to simulate vertical mixing of phytoplankton and to keep the $\mathrm{pH}$-values in the cultures below 8.4. On reaching a density of $\sim 8$ million cells $1^{-1}$ in batch mode (i.e., medium dilution rate $D=0$ ), the peristaltic pumps were started to keep the cells in exponential-phase growth. Pumping rates were varied until $D$ balanced cell division rates $(\mu)$ that were at maximum $D=v / V$ in which $\nu=$ pumping rate $\left(1 \mathrm{~d}^{-1}\right) ; V=$ culture volume (1). $\mu=D+\left[\ln \left(N_{t} / N_{t-\Delta t}\right) / \Delta t\right]$ in which $N=$ cell number (cells ${ }^{-1}$ ) $t=$ time (d); $\Delta t=$ time interval of sampling (d). Steady-state $(\mu=D)$ light-limited growth thus achieved was monitored by cell counting. When cell numbers showed a fluctuation of more than $20 \%$ the pumping rate $(v)$ was corrected (Rijstenbil and Wijnholds 1991).

\section{Experimental design}

In the first culture ( $\mathrm{Zn}-$ ) the medium contained $40 \mathrm{n} M$; in the second culture $(\mathrm{Zn}+)$ the medium contained $140 \mathrm{n} M$ total dissolved $\mathrm{Zn}$. Light-limited cells grew at an initial $\mathrm{Cu}$ concentration of $\sim 3 \mathrm{nM}$. The $\mathrm{Cu}$ concentration in the continuous cultures was then stepwise increased via dilution, using media with 40,80 , and $120 \mathrm{n} M \mathrm{CuSO}_{4}$, respectively (Fig. 1). Using the MINEQL (Mineral Equilibrium) model, $\mathrm{Cu}$ speciation in the cultures was calculated in relation to the other trace metals ( $\mathrm{Fe}, \mathrm{Mn}, \mathrm{Co}, \mathrm{Zn}$ ) added to the medium, as well as

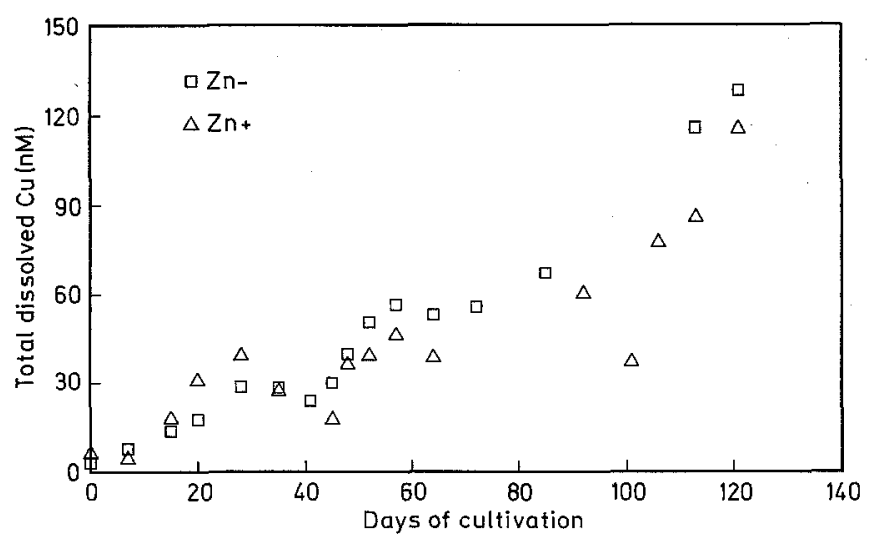

Fig. 1 Ditylum brightwellii. Increase of total dissolved $\mathrm{Cu}$ with time, in light-limited continuous cultures grown at $40 \mathrm{n} M(\mathrm{Zn}-)$ and $140 \mathrm{n} M \mathrm{Zn}(\mathrm{Zn}+)$; days of sampling on horizontal axis to the ligands added (EDTA) or produced by the algae (Gerringa et al. in press)

To compare effects of increasing $\mathrm{Cu}$ at two different levels of $\mathrm{Zn}$, samples were taken in the course of the 121-d experiment, at the end of the first photoperiod (10:00 hrs). Metal-induced decreases of growth rates $(\mu)$ were monitored by cell counting and balanced by the pump speed to restore the steady state (light-limited growth).

\section{Cell counting and sinking rate, SEM (scanning electron} microscopic) preparations

Cell samples (2-ml) were taken from the cultures and preserved in Lugol's iodine. Cells were counted (cells $1^{-1}$ ) under an inverted microscope (Olympus CKBIN). Length and diameter $(\mu \mathrm{m})$ of 100 cell frustules per sample were measured with an Olympus IM VIDS image analyzer. Mean cell volumes $\left(\mu \mathrm{m}^{3}\right)$ were calculated. To normalize cell parameters to units cell volume, we calculated with the biovolume as a biomass standard (Rijstenbil et al. 1989):

Biovolume $=($ cell volume $\times$ cell numbers $)$.

Cell reproductive stages were examined, distinguishing vegetative and presexual cells, zygotes and auxospores, according to Waite and Harrison (1992). Sinking rates of Ditylum brightwellii were determined at $15^{\circ} \mathrm{C}$ in a 5-ml tubular plankton settling chamber with a thin bottom blass (Hydrobios, Kiel), placed on the inverted microscope. The cylinder was filled with $4 \mathrm{ml}$ culture medium [column height $(h)=2 \mathrm{~cm}$ ] with the appropriate $\mathrm{Cu}$ concentration. Using a variable pipette, $0.2 \mathrm{ml}$ algal suspension was carefully transferred in a thin layer on top of the medium, at $t=0$ (Bienfang 1980). From $t=0$ to $90 \mathrm{~min}$, at 10 -min intervals, the cells $(N)$ settled on the bottom of the chamber were counted (cells $\mathrm{cm}^{-2}$ ). Final cell numbers $\left(N_{\infty}\right)$ on the bottom of the chamber were determined at $t=90 \mathrm{~min}$. The microscope lamp was on only during counting. Accumulated numbers of settled cells followed a normal S-shaped frequency distribution pattern in time (Bienfang 1980). The (bell-shaped) differential curve with the change in cell numbers at each time $(\Delta N)$ was derived. Fractions of settled cells $\left(F_{t}=\Delta N / N_{\infty}\right)$ were given for each interval. The mean ( $\approx$ optimum) settling time is

$t_{\mathrm{AVG}}=\left(1 / N_{\infty}\right) \times \sum_{t=0}^{t=90}[\Delta N \times t]=\sum_{t=0}^{t=90}\left[F_{t} \times t\right] \quad(\mathrm{min})$.

With $t_{\text {AVG }}$ and $h=2 \mathrm{~cm}$, we calculated the mean sinking rates of $D$. brightwellii as

$v_{\mathrm{AVG}}=h /\left[t_{\mathrm{AVG}} /(60 \times 24)\right]=0.02 \times 60 \times 24 / t_{\mathrm{AVG}}=28.8 / t_{\mathrm{AVG}}\left(\mathrm{m} \mathrm{d}^{-1}\right)$.

for cells growing at 3,40,80 and $120 \mathrm{n} M$ total dissolved $\mathrm{Cu}$.

For SEM, $15 \mathrm{ml}$ cell suspension of Ditylum brightwellii was fixed $(1 \mathrm{~h})$ with $2 \%(\mathrm{w} / \mathrm{v})$ glutaraldehyde (GA) in HEPES $\mathrm{pH} 7.8$, washed three times in $14 \% 0 \mathrm{~S}$ isotonic medium, post-fixed with $2 \%(\mathrm{w} / \mathrm{v})$ $\mathrm{OsO}_{4}(1 \mathrm{~h})$, and washed again in isotonic medium. Microscope slides were pretreated with poly-L-lysine to make cells stick to the glass. Attached cells were washed in subsequently $30,50,70,90$ and (three times) $100 \%(\mathrm{v} / \mathrm{v})$ ethanol, and transferred into a $\mathrm{CO}_{2}$ atmosphere in a critical point dryer (Balzers CPD 020). Temperature was increased to $40^{\circ} \mathrm{C}$ ( 85 bar), and $\mathrm{CO}_{2}$ was then slowly evacuated. After drying, samples were gold-coated at 0.1 Torr. Cells were observed with a Jeol JSM-T300 scanning electron microscope.

HPLC (high performance liquid chromatographic) analysis of cellular thiols

For the HPLC-analysis of the free-SH groups in the reduced thiol antioxidants, we applied a post-column derivatization with $5,5^{\prime}$ dithiobis-2-nitrobenzoic acid (DTNB), according to Gekeler et al. (1988) with sulfosalicylic acid (SSA) instead of sodium borohydride. Cells were harvested and concentrated by centrifugation $(1000 \mathrm{~g}$; $\left.15 \mathrm{~min} ; 0^{\circ} \mathrm{C}\right) ; 50$ to $100 \mathrm{mg}$ freeze-dried cells $(48 \mathrm{~h})$ were ground with a pestle and mortar $\left(0^{\circ} \mathrm{C}\right)$. The powder was suspended in $1 \mathrm{ml}$ of buffer with $236 \mathrm{~m} M$ SSA and $6.3 \mathrm{~m} M$ DTPA (diethylenetriaminepentaacetic acid, $\mathrm{pH}$ 2) to keep $\mathrm{SH}$ reduced. The suspension was sonicated $\left(0^{\circ} \mathrm{C}\right.$; MSE Soniprep 10 , amplitude $\left.14 \mu \mathrm{m}\right)$ and centrifuged $\left(12000 \mathrm{~g} ; 20 \mathrm{~min} ; 0^{\circ} \mathrm{C}\right)$ to remove cell residues. The supernatants (cytosol extracts) were stored at $-70^{\circ} \mathrm{C}$ and used later for $\mathrm{SH}$-anal- 
ysis (Rijstenbil et al. in press). 50- $\mu$ l extracts were injected into an HPLC-system (LKB Pharmacia) consisting of a controller, PMV-7 injection valve, mixing chamber and HPLC pump 2248-107 and UVVIS detector 2141. Optimum separation of SH peaks was obtained, using a reverse-phase $\mathrm{C}_{2} / \mathrm{C}_{18}$ HPLC column (Pharmacia Superpac PepS $)$ and the solvents $\mathrm{A}$ [water $\left(0.05 \%\right.$ v/ $\left.\left./ \mathrm{H}_{3} \mathrm{PO}_{4}, \mathrm{pH} 2.5\right)\right]$ and $\mathrm{B}$ (100\% acetonitril). At a pump flow of $1 \mathrm{ml} \mathrm{min}{ }^{-1}$, the following separation programme was used: 0 to 6 min 100\% solvent A (isocratic); 6 to $33 \mathrm{~min}, 0$ to $40 \%$ solvent B (linear). Thiols were detected via a post-column SH reaction $\left(0.6 \mathrm{~m} M\right.$ DTNB in $50 \mathrm{~m} M \mathrm{KH}_{2} \mathrm{PO}_{4} \mathrm{pH} 7.6$; flow $=1 \mathrm{ml} \mathrm{min}{ }^{-1}$; reaction time $=1.0 \mathrm{~min}$; wavelength $=412 \mathrm{~nm}$ ). Retention times and $\mathrm{SH}$ concentrations were obtained via standards of gammaglutamylcystein (Sigma), glutathione (Merck) and purified Silene-phytochelatins (gammaglutamylcysteinyl $\mathrm{n}_{\mathrm{n}}$-glycines: $\mathrm{n}=2,3$; Free Univ. Amsterdam), in $236 \mathrm{~m} M$ SSA. SH-concentrations were normalized to g dry weight ( $\mu \mathrm{mol} \mathrm{SH} \mathrm{g}{ }^{-1}$ dry wt).

\section{Superoxide dismutase activity}

Duplicate $100-\mathrm{ml}$ samples of cells were filtered on $0.45-\mu \mathrm{m}$ Tuffryn membrane discs (Gelman Sciences), and suspended into $2 \mathrm{ml}$ $0.05 \mathrm{M} \mathrm{KH}_{2} \mathrm{PO}_{4}$ extraction buffer ( $\mathrm{pH} 7.8$ ) containing $0.1 \mathrm{mM}$ ED$\mathrm{TA}$, and sonicated on ice $\left(0^{\circ} \mathrm{C}\right)$ for $3 \mathrm{~min}$ (MSE Soniprep 150, amplitude $14 \mu \mathrm{m}$ ). Cell residues were removed by a 15 min centrifugation at $8000 \mathrm{~g}\left(0^{\circ} \mathrm{C}\right)$. The supernatant was used as enzyme solution for measurement of the superoxide dismutase (SOD) activity according to McCord and Fridovich (1969). SOD activities were calculated according to Asada et al. (1974). The principle is that superoxide anion radicals $\left(\mathrm{O}_{2}^{-}\right)$, generated by the xanthine-xanthine oxidase (XOD) system, reduce cytochrome $c$. Inhibition of cytochrome $c$ reduction by SOD was continuously monitored at $550 \mathrm{~nm}$ (Kontron Uvikon 940 spectrophotometer). Each assay was performed five times at $25^{\circ} \mathrm{C}$ in $1.5 \mathrm{ml}$ reaction mixture with: $0.05 \mathrm{MKH}_{2} \mathrm{PO}_{4}(\mathrm{pH}$ 7.8), $0.1 \mathrm{~m} M$ EDTA, $10 \mu M$ ferricytochrome $c, 50 \mu M$ xanthine (Sig$\mathrm{ma}$ ) and $5.4 \mu \mathrm{g}$ XOD (Sigma). The SOD unit (per $\mathrm{mm}^{3}$ cell volume) is defined as the amount of enzyme required for a $50 \%$ inhibition of ferricytochrome $c$ reduction.

\section{Photosynthesis}

$\mathrm{O}_{2}$-evolution was measured in 200-ml cell suspensions as described by Rijstenbil et al. (1989) and Rijstenbil and Wijnholds (1991). Photosynthetic rates were measured at irradiance values of $0,100,200$, $300,400,500$ and $600 \mu \mathrm{mol}$ quanta $\mathrm{m}^{-2} \mathrm{~s}^{-1}$. These rates were used to draw the $P-I$ (photosynthesis-irradiance) curves, and initial slopes of this curve rendered the photosynthetic affinity $(\alpha)$. As described in Rijstenbil et al. (1989), the $\alpha$ values were normalized to cell volume $\left[\mathrm{mMO}_{2} \mathrm{~h}^{-1}\left(\mu \mathrm{mol} \text { quanta } \mathrm{m}^{-2} \mathrm{~s}^{-1}\right)^{-1}\right]$.

\section{Analyses of pigments and cellular carbon}

100-ml cell suspensions were collected on Whatman GF/C glassfibre filters. Diatom pigments (chlorophyll $a$ and $c$ ) were HPLC-analyzed (Waters Ass.) using $100 \%$ methanol and $2 \%$ ammonium acetate as an extraction mixture instead of $90 \%$ acetone (Gieskes and Kraay 1983). Cellular carbon was measured on a Carlo Erba NA1500 NC-analyzer (Rijstenbil and Wijnholds 1991).

\section{Metal analyses}

Culture samples were collected in glass bottles, previously cleaned with dilute acid and were equilibrated with medium before use. Samples were filtered under a low $\mathrm{N}_{2}$ pressure through $0.45-\mu \mathrm{m}$ cellulose nitrate filters in a polyethylene filtration set. To avoid cell rupture, the collecting bottle was removed before filters became dry. Filters were destroyed in a Plasma Processor 200-G (Technics GmbH) and ashes were dissolved in $\mathrm{HCl} / \mathrm{HNO}_{3}$. Particulate $\mathrm{Cu}$ and $\mathrm{Zn}$ were measured with GFAAS (Perkin Elmer Zeeman 3030). Cellular metal contents were normalized to cell volume. For total dissolved $\mathrm{Cu}$ and $\mathrm{Zn}$, filtrates $(<0.45 \mu \mathrm{m})$ were acidified to $\mathrm{pH}=2$. After a $4-\mathrm{h}$ $\mathrm{UV} / \mathrm{H}_{2} \mathrm{O}_{2}$ destruction, metals were analyzed with differential pulse anodic stripping voltammetry (DPASV) using a hanging drop mercury electrode and analyzer (EG \& G PAR 303A/384B, Princeton, $\mathrm{NJ}$ - USA), collection potential $-0.6 \mathrm{~V}$.

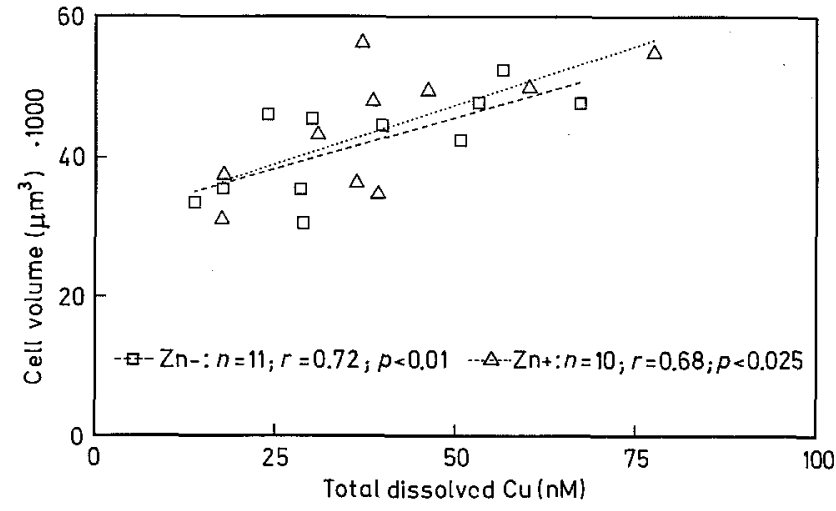

Fig. 2 Ditylum brightwellii. Valves volume of intact cells grown at $40 \mathrm{n} M(\mathrm{Zn}-)$ and $140 \mathrm{n} M \mathrm{Zn}(\mathrm{Zn}+)$ vs dissolved $\mathrm{Cu}$ in the medium

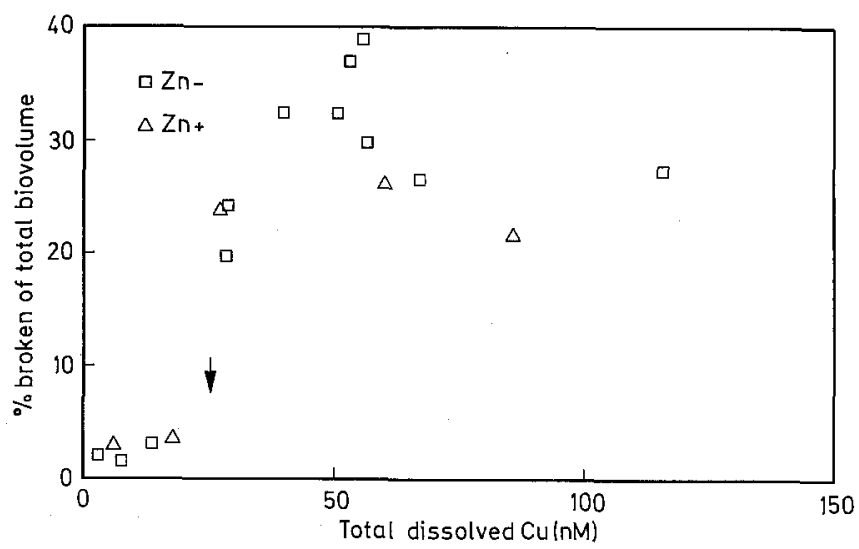

Fig 3 Ditylum brightwellii. Percentage of the volume of broken valves relative to total biovolume; cells grown at $40 \mathrm{n} M(\mathrm{Zn}-)$ and $140 \mathrm{n} M \mathrm{Zn}(\mathrm{Zn}+)$ vs total dissolved $\mathrm{Cu}$ [Arrow increase of free $\mathrm{Cu}^{2+}$ (MINEQL-calculated)]. Cellular $\mathrm{Cu}$ content $\sim 8 \mu M$

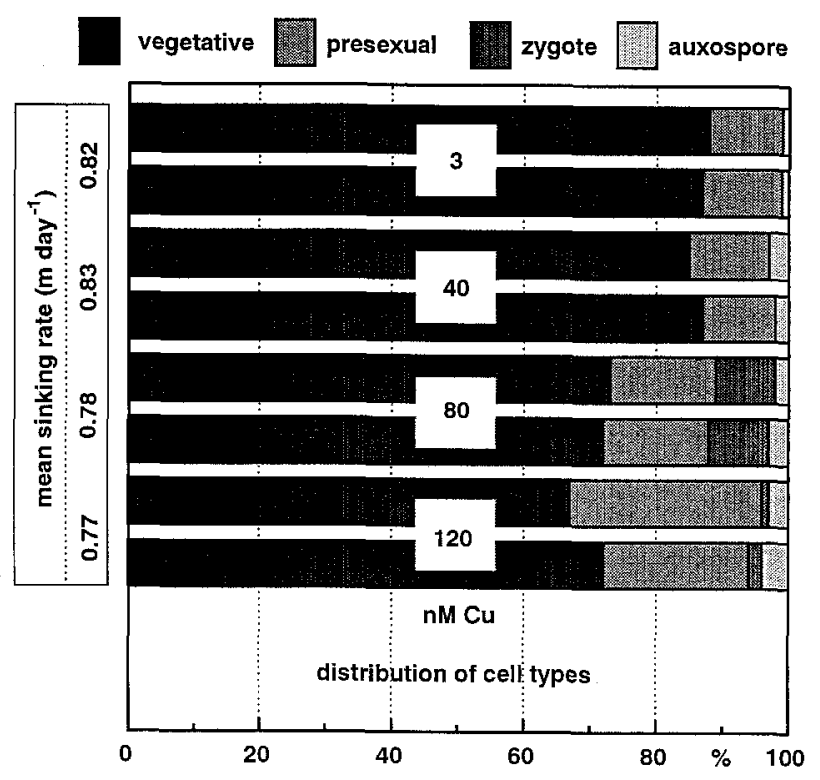

Fig. 4 Ditylum brightwellii. Percentage of vegetative and sexual reproductive cell stages at $3,40,80$ and $120 \mathrm{n} M$ total dissolved $\mathrm{Cu}$. Mean cell sinking rates $\left(\mathrm{m} \mathrm{d}^{-1}\right)$ indicated to the left 

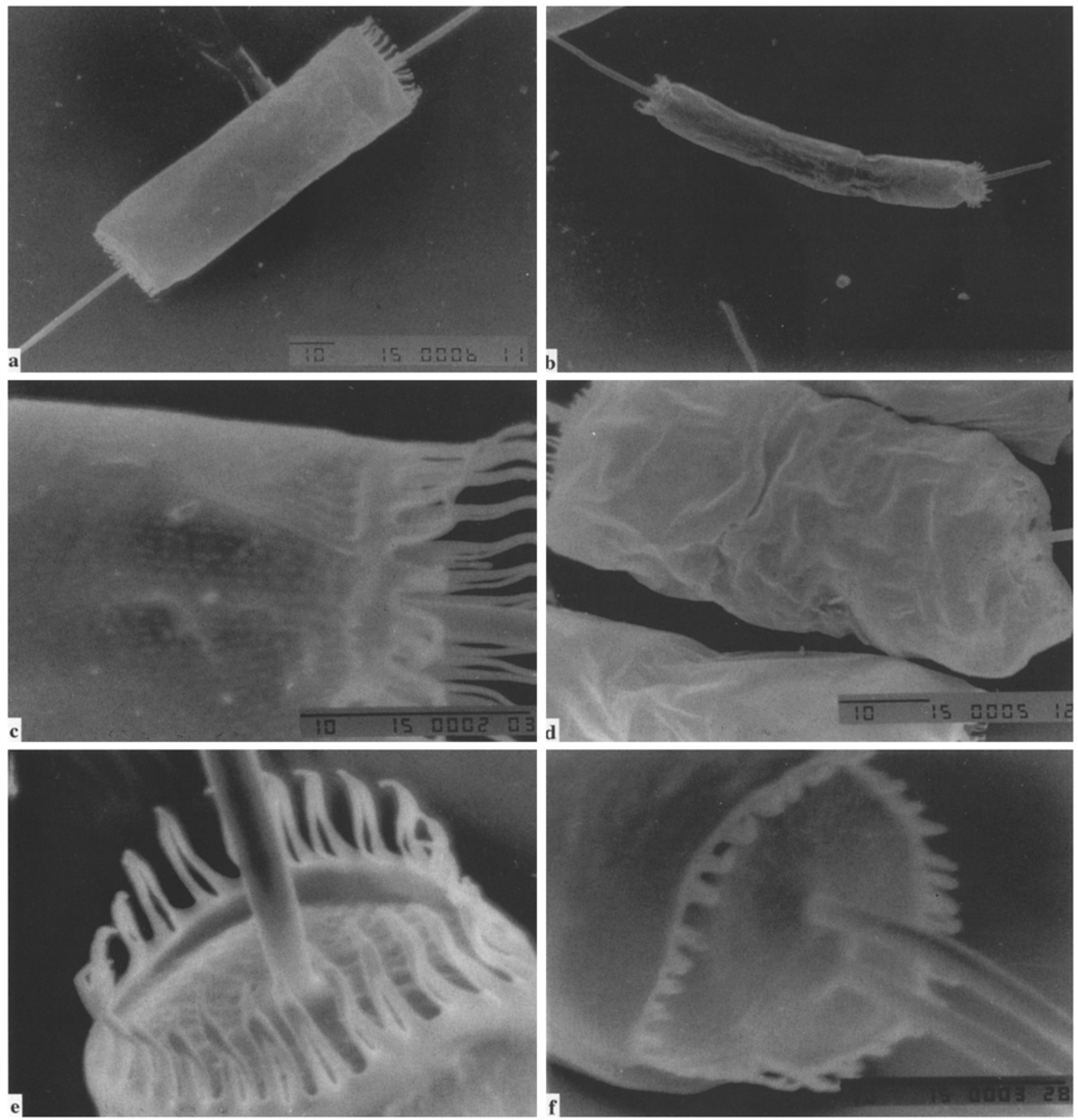

Fig. 5 Ditylum brightwellii. Scanning electron microphotographs of cells grown at $10 \mathrm{n} M(\mathbf{a}, \mathbf{c}, \mathbf{e})$ and $80 \mathrm{n} M(\mathbf{b}, \mathbf{d}, \mathbf{f})$ total dissolved $\mathrm{Cu}$. a Intact cell at $10 \mathrm{nM} \mathrm{Cu}$; b presexual cell with increased surface roughness at $80 \mathrm{nM} \mathrm{Cu}$; c close-up of a smooth surface at $10 \mathrm{n} M \mathrm{Cu} ; \mathbf{d}$ wrinkled cell at $80 \mathrm{n} M \mathrm{Cu}$; e normal, single labiate processus; $\boldsymbol{f}$ double labiate processi, appearing after extended exposure to $\mathrm{Cu}(80 \mathrm{n} M)$

\section{Results}

Total dissolved $\mathrm{Zn}$ was $45 \pm 11 \mathrm{n} M$ in the $\mathrm{Zn}$ - culture ( $40 \mathrm{n} M$ ) added), and $64 \pm 36 \mathrm{n} M$ in the $\mathrm{Zn}+$ culture (140 $\mathrm{n} M$ added). Loss of dissolved $\mathrm{Zn}$ in the $\mathrm{Zn}+$ culture was a result of co-precipitation with silicate at $\mathrm{pH}$ 8.4. The amount of $\mathrm{Zn}$ adhering to the glass of the culture vessel was negligible, as the sum of total dissolved and algal $\mathrm{Zn}$ $(146 \mathrm{n} M)$ gave a full recovery of the amount added to the culture media ( $140 \mathrm{nM})$. About $72 \%$ of total $\mathrm{Zn}$ was incorporated into the Si-coated cell wall matrix of Ditylum 
brightwellii (Gerringa et al. in press). Algal Zn contents showed wide variations. Normalizing $\mathrm{Zn}$ to algal cell carbon gave $110 \pm 30 \mu \mathrm{mol} \mathrm{Zn} \mathrm{mol}^{-1} \mathrm{C}$ for the $\mathrm{Zn}-$ cells, and $172 \pm 53 \mu \mathrm{mol} \mathrm{Zn} \mathrm{mol}{ }^{-1} \mathrm{C}$ for the $\mathrm{Zn}+$ cells. The same applied to $\mathrm{Zn}$ contents normalized to diatom biovolume. $\mathrm{Zn}-$ cells contained $179 \pm 54 \mu M \mathrm{Zn}, \mathrm{Zn}+$ cells contained $337 \pm 175 \mu M \mathrm{Zn}$. A $t$-test for difference among pairs of means among $\mathrm{Zn}-$ and $\mathrm{Zn}+$ cells (Sokal and Rohlf 1981) proved that $\mathrm{Zn}$ contents were significantly higher in the $\mathrm{Zn}+$ culture $(p<0.01)$. Moreover, cellular $\mathrm{Zn}$ increased significantly with cellular $\mathrm{Cu}$ in the $\mathrm{Zn}+$ culture, as $[\mathrm{Zn}]=$ $15 \times[\mathrm{Cu}]+90(\mu M)(n=11 ; r=0.54 ; p<0.05)$. The designed increase of total dissolved $\mathrm{Cu}$ with time (Day 1 to 121) was the same in cultures $\mathrm{Zn}-$ and $\mathrm{Zn}+$ (Fig. 1). In both cultures, total algal $\mathrm{Cu}$ contents comprised $\sim 10 \%$ of total dissolved $\mathrm{Cu}$ throughout the experiment. Cellular $\mathrm{Cu}$, normalized to biovolume $(\mu M)$ increased with dissolved $\mathrm{Cu}(\mathrm{Zn}-: n=12$; $r=0.76 ; p<0.005$ vs $\mathrm{Zn}+: n=11 ; r=0.59 ; p<0.05)$, but $\mathrm{Cu}$ levels in $\mathrm{Zn}+$ cells were not significantly higher ( $t$-test) than in $\mathrm{Zn}$ - cells. As a result of an increase of cell volume in the total dissolved $\mathrm{Cu}$-gradient from 10 to $80 \mathrm{nM}$ (Fig. 2), $\mu \mathrm{mol} \mathrm{Cu} 1^{-1}$ biovolume did not increase linearly with dissolved $\mathrm{Cu}$. The relative biovolume of broken cells frustules increased when total dissolved $\mathrm{Cu}$ exceeded 25 $\mathrm{n} M$ (Fig. 3) and calculated ionic $\mathrm{Cu}$ increased from $10^{-11}$ to $10^{-9.7} M$ (MINEQL model: Gerringa et al. in press). Due to cell breakage, part of the cellular $\mathrm{Cu}$ may have been released into the medium, with the remaining $\mathrm{Cu}$ still adsorbed to the cell fragments.

Cells intensified their sexual reproduction at increasing $\mathrm{Cu}$ (Fig. 4). Increasing cell volumes were probably caused by a larger proportion of auxospores and post-auxospore, vegetative cells. Sinking rates showed a minor decrease with increasing $\mathrm{Cu}$ (Fig. 4). However, due to an overlap of frequency distributions of settled cell fractions vs time, this decrease was not significant. Apart from disintegrated cells and reproductive stages, deformed cells were found in increasing numbers. It was estimated that a 3 -fold increase of curved, presexual (Fig. 5b) and "wrinkled" (Fig. 5d) cells occurred at $80 \mathrm{n} M \mathrm{Cu}$, relative to observations at $10 \mathrm{nM} \mathrm{Cu}$ (Fig. $5 \mathrm{a}, \mathrm{c}$ ). Cells with more than one labiate processus at both ends were more frequently present (Fig. 5f).

At the start of the experiment, steady-state cell division rates were $\sim 0.45 \mathrm{~d}^{-1}$ in the $\mathrm{Zn}-$, and $\sim 0.37 \mathrm{~d}^{-1}$ in the $\mathrm{Zn}+$ culture. Growth rates decreased gradually with increasing $\mathrm{Cu}$, and dilution rates $(D)$ were reduced accordingly to maintain a biomass of $\sim 12.5$ million cells $1^{-1}$. Division rates $(\mu / \mathrm{ln} 2)$ in the $\mathrm{Zn}+$ culture $(140 \mathrm{n} M \mathrm{Zn})$ were lower than those in the $\mathrm{Zn}-$ culture $(140 \mathrm{n} M \mathrm{Zn})$, and indicated a cumulative effect of $\mathrm{Zn}$ (Fig. 6). In both cultures division rates decreased significantly with cellular $\mathrm{Cu}(\mathrm{Zn}-$ : $n=15 ; r=-0.47 ; p<0.05$ and $\mathrm{Zn}+: n=14 ; r=-0.67$; $p<0.005)$.

A decrease of reduced glutathione (GSH) was observed at increasing cellular $\mathrm{Cu}$ (Fig. 7). GSH was the only thiol detectable via this HPLC-DTNB method. Phytochelatins, if present, were below the limit of detection. SOD activity per cell increased with $\mathrm{Cu}$ in $\mathrm{Zn}-(n=10 ; r=0.54 ; p<0.05)$

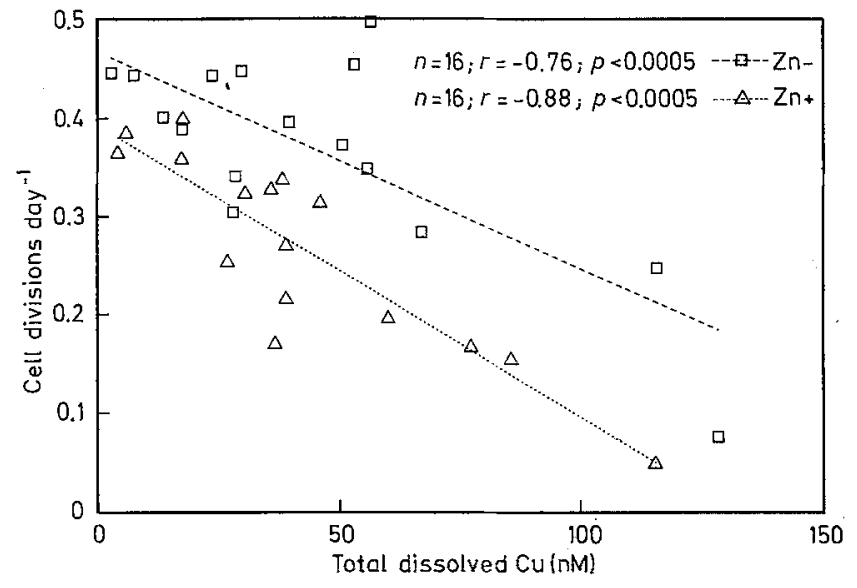

Fig. 6 Ditylum brightwellii. Cell division rates vs increasing concentrations of total dissolved $\mathrm{Cu}$ in light-limited continuous cultures, grown at $40 \mathrm{n} M(\mathrm{Zn}-)$ and $140 \mathrm{n} M \mathrm{Zn}(\mathrm{Zn+})$

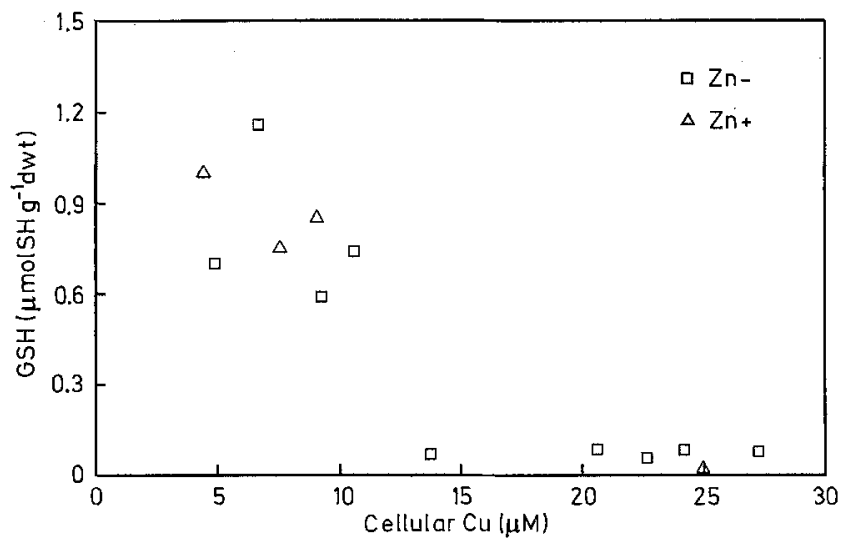

Fig. 7 Ditylum brightwellii. Reduced glutathione $(G S H)$ in cytosolic fractions of cells grown at $40 \mathrm{n} M(\mathrm{Zn}-)$ and $140 \mathrm{n} M \mathrm{Zn}(\mathrm{Zn}+)$ vs concentrations of cellular $\mathrm{Cu}$. The concentration of free thiol groups in GSH (reduced glutathione) is expressed in $\mu \mathrm{mol} \mathrm{SH} \mathrm{g}{ }^{-1}$ dry wt

and $\mathrm{Zn}+$ cells $(n=9 ; r=0.59 ; p<0.05)$. SOD activity, normalized to cell volume, increased with cellular $\mathrm{Cu}$ in both $\mathrm{Zn}-$ and $\mathrm{Zn}+$ cultures (Fig. 8).

Chlorophyll $c$ contents, normalized to cell volume, were not influenced by increasing cellular $\mathrm{Cu}$. Contents were lower in $\mathrm{Zn}+$ cells than in $\mathrm{Zn}$ - cells $\left(0.09 \pm 0.03 \mathrm{~g} \mathrm{l}^{-1}\right.$ and $0.15 \pm 0.04 \mathrm{~g} \mathrm{l}^{-1}$, respectively; $t$-test: $\left.p<0.0005\right)$. In both $\mathrm{Zn}-$ and $\mathrm{Zn}+$ cells, chlorophyll $a$ decreased considerably with increasing cellular $\mathrm{Cu}$ (Fig. 9a). In chlorophyll $a: c$ ratios, however, clear differences existed between $\mathrm{Zn}-$ and $\mathrm{Zn}+$ cells (Fig. $9 \mathrm{~b}$ ). This was the result of an initial chlorophyll $a: c$ ratio of $\sim 5$ in $\mathrm{Zn}+$ cells, whereas in $\mathrm{Zn}-$ cells initial ratios were $\sim 3$. The decrease in chlorophyll $a$ resulted in decreased photosynthetic affinities $(\alpha)$, which means that the cells gradually lost their ability to efficiently evolve $\mathrm{O}_{2} \cdot \mathrm{Cu}$ damaged the photosynthetic apparatus equally in $\mathrm{Zn}-$ and $\mathrm{Zn}+$ cells (Fig. 9c). 


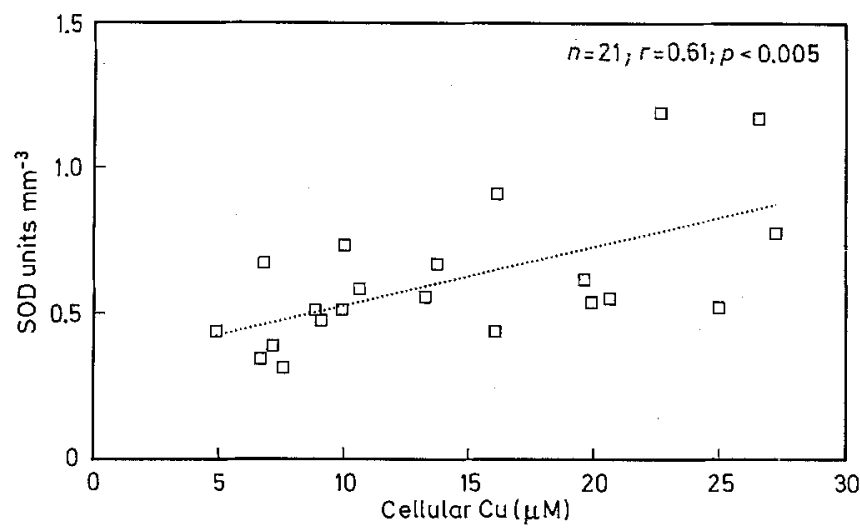

Fig. 8 Ditylum brightwellii. Superoxide dismutase activity (SOD) vs cellular $\mathrm{Cu}$ in $\mathrm{Zn}-$ and $\mathrm{Zn}+$ cultures (combined data)
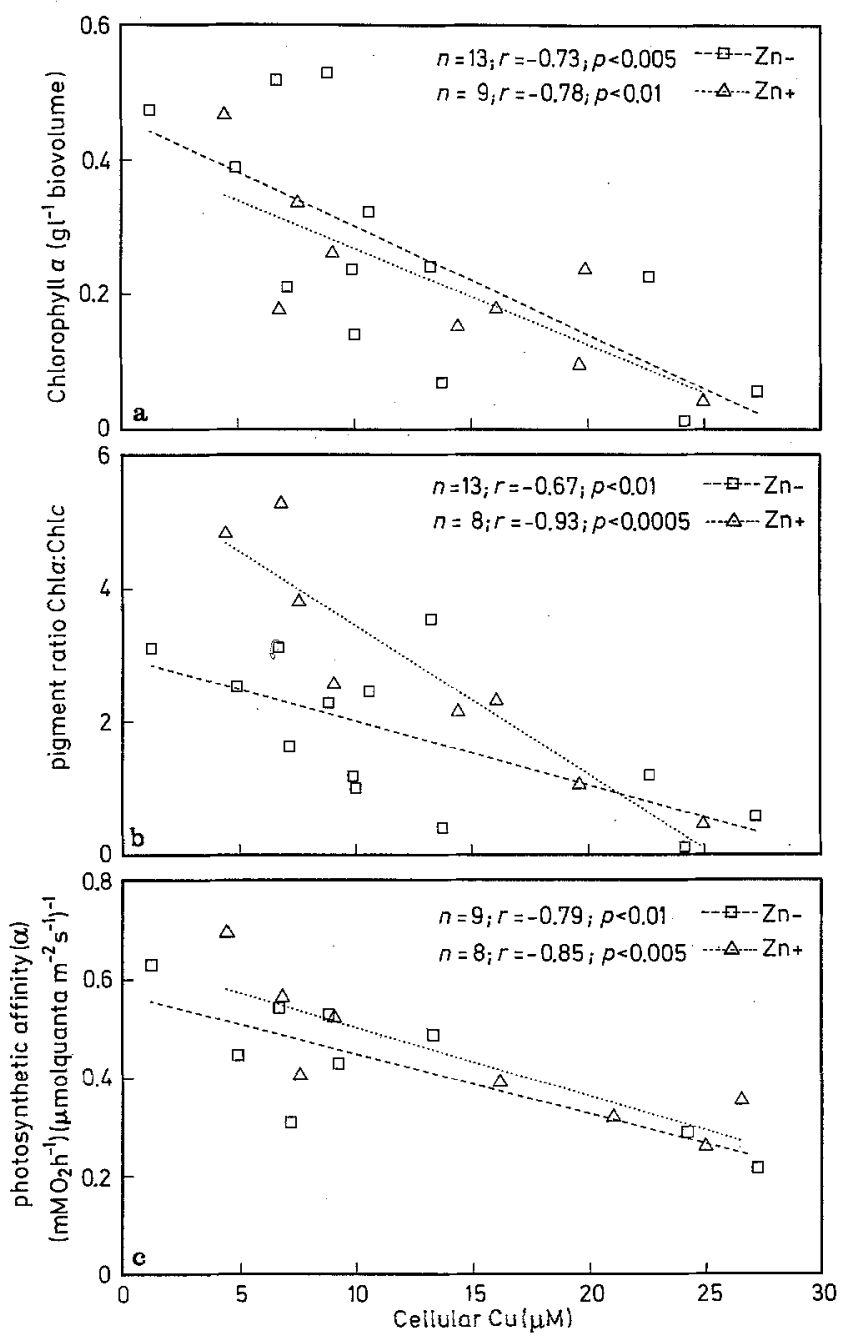

Fig. 9 Ditylum brightwellii. Values of: a chlorophyll a contents; b chlorophyll $a: c$ ratio; c photosynthetic affinities $(\alpha)$ plotted vs $\mathrm{Cu}$ contents of cells grown at $40 \mathrm{nM}(\mathrm{Zn}-)$ and $140 \mathrm{n} M \mathrm{Zn}(\mathrm{Zn}+)$

\section{Discussion}

Increasing $\mathrm{Cu}$ levels have affected the cell structure and integrity of Ditylum brightwellii. An increase of cell volumes (Fig. 2) upon Cu stress has been reported before in diatoms (Fisher et al. 1981; Rijstenbil and Wijnholds 1991). Disturbance of silicon deposition, due to a $\mathrm{Cu}$-induced lipid peroxidation in the Golgi apparatus (Lee and Li 1991), might have caused wall deformation. Increasing volumes and surface roughness (Fig. $5 \mathrm{~d}$ ) may contribute to an increased metal binding capacity. Gerringa et al. (in press) observed an increase of the adsorption capacity from $\sim 2.5$ to $7.5 \mu$ equiv $\mathrm{Cu} \mathrm{m}^{-2}$ cell surface upon a gradual increase from 10 to $126 \mathrm{nM} \mathrm{Cu}$ in the medium. Although an increased metal sorption in the wall may diminish internalization of $\mathrm{Cu}$ in $D$. brightwellii, it is doubtful that the gradual increase of $\mathrm{Cu}$ induced a tolerance, as suggested by Twiss et al. (1993). Such an adaptive response would be in contradiction with the increase of broken cells (Fig. 3). In general, breakage follows membrane leakage due to lipid peroxidation (Fisher et al. 1981). Probably as a result of an increased leakage of organic $\mathrm{Cu}$-complexing ligands (Gerringa et al. in press), the competition between ligands and cells (Hudson and Morel 1993) caused a stabilization of calculated $\mathrm{Cu}^{2+}$ at $0.2 \mathrm{nM}$ (MINEQL model) in spite of a further $\mathrm{Cu}$ increase. Thus, ligands excreted by $D$. brightwellii passively reduced $\mathrm{Cu}$ availability and cannot be regarded as a tolerance (detoxification) mechanism (Foster 1977; Härdstedt-Roméo and Gnassia-Barelli 1980).

The relative increase of sexual stages in Ditylum brightwellii was one of the major causes of cell enlargement (Fig. 4). According to Waite and Harrison (1992), these cell types have a higher sinking speed and may use this feature to escape from a toxic environment. However, as sinking rates were hardly affected by $\mathrm{Cu}$, it is possible that the increased wall roughness gave some additional resistance against sinking (Fig. 5 d, f). Cu-induced oxyradicals damage DNA, oxidize GSH, and hence, affect genetic composition and mitosis (Lewis 1984; Floyd et al. 1986; Stauber and Florence 1987; Wingate et al. 1988; Milne et al. 1993). Auxospore formation resulted from an accelerated recombination of DNA through male gametes and egg cells. We cannot rule out the possibility that metal-tolerant cells evolve via genetic selection (Cha and Cooksey 1993; Voloudakis et al. 1993), as it is a common feature of diatoms to constantly change their genetic composition (Armbrust and Chisolm 1992). Here, sexual reproduction should be considered as a non-specific and, as regards avoidance of oxidative damage, ineffective stress response (Drebes 1977).

SH-groups in cysteine are effective in detoxification, forming cytosolic metal-complexes (Kosakowska et al. 1988). In many algae, phytochelatins (poly-gammaglutamylcysteinyl-glycines) are induced by heavy metals (Gekeler et al. 1988; Reed and Gadd 1990; Wikfors et al. 1991; De Vos et al. 1992). Phytochelatins were not detectable in Ditylum brightwellii, and the rapid decline of the small pool of reduced GSH (Fig. 7) indicated that it might be oxidized 
by $\mathrm{Cu}$. Glutathione (GSH: gammaglutamylcysteinyl-glycine) is the major cellular ligand in metal homeostasis and implicitly protects against oxyradicals whose formation is catalyzed by the transition metal $\mathrm{Cu}$ (Miller et al. 1990). Due to its low GSH:GSSG redox ratios, D. brightwellii might be rather sensitive to $\mathrm{Cu}$-induced oxidative stress (Rijstenbil et al. in press).

SOD is a prominent enzymatic biomarker of defense against oxidative stress (Van Assche and Clijsters 1990; Chongpraditnun et al. 1992). It transfers $\mathrm{O}_{2}^{-}$radicals into $\mathrm{H}_{2} \mathrm{O}_{2}$. In previous work, SOD activities increased in $\mathrm{Zn}$ exposed Ditylum brightwellii (Rijstenbil et al. in press). SOD activities increased with $\mathrm{Cu}$, independent of the $\mathrm{Zn}$ contents (present work), which indicates that $\mathrm{Cu}$ is the only oxidative stressor (Salin 1987; Van Assche and Clijsters 1990).

A lack of antioxidant defense will cause oxyradical damage in chloroplasts, and inhibition of algal photosynthesis. Chlorophyll $c$ contents were low, and chlorophyll $a: c$ ratios were high in $\mathrm{Zn}+$ cells (Stauber and Jeffrey 1988). A doubled amount of cellular Zn did not affect photosynthesis (Fig. 9c), but cell division was suppressed in $\mathrm{Zn}+$ cells (Fig. 6) (Stauber and Florence 1990; Rijstenbil and Poortvliet 1992). Chlorophyll $a$ proved to be sensitive to $\mathrm{Cu}$, and its decrease coincided with the decrease of photosynthetic activity. As in former experiments, a decrease of photosynthetic affinity $(\alpha)$ was caused by $\mathrm{Cu}$ (Rijstenbil and Wijnholds 1991, Rijstenbil et al. in press). A competitive inhibition at metal binding sites in the photosystems, disturbance of photosynthetic electron transport, pigment breakdown and lipid peroxidation in chloroplasts have been described as damaging effects of the oxidative metal Cu (Sandmann and Böger 1980; Baszynski et al. 1988; De Vos et al. 1989; De Vos and Schat 1991; Ahmed and Abdel-Basset 1992; Mishra et al. 1993).

To summarize, the long-term exposure to $\mathrm{Cu}$ did not increase tolerance in Ditylum brightwellii. Evidence for stress avoidance, as a result of increasing $\mathrm{Cu}$ adsorption capacity or accelerated sexual reproduction, could not be provided. Metal detoxification mechanisms were not activated, and GSH pools were soon depleted. Although SOD increasingly eliminated the $\mathrm{O}_{2}^{-}$radicals formed, the prooxidant $\mathrm{Cu}$ gradually caused a loss of photosynthetic performance, a decrease of chlorophyll $a$, enlargement, deformation and breakage of cells.

Acknowledgements The authors thank Dr. J. A. C. Verkleij and his team (Plant Ecol. and Ecotoxicol. Free Univ. Amsterdam-NL) for their advice concerning anti-oxidant analysis, and the staff of the Botanical Dept., Catholic Univ. Nijmegen-NL for the use of the SEM facilities. We are grateful for the criticism of the three anonymous reviewers. This is Communication No. 724 of NIOO-CEMO (Yerseke-NL).

\section{References}

Ahmed ZA, Abdel-Basset R (1992) Growth, photosynthesis, and proline content of Scenedesmus obliquus (Turp.) Kütz. as affected by $\mathrm{Cu}^{+2}$. Acta hydrobiol Krákow 34: 401-409
Armbrust EV, Chisolm SW (1992) Patterns of cell size change in a marine centric diatom: variability evolving from clonal isolates. J Phycol 28: 146-156

Asada K, Takahashi M, Nagate M (1974) Assay and inhibitors of spinach superoxide dismutase. Agr biol Chem 38:471-473

Baszynski T, Tukendorf A, Ruszkowska M, Skorzynska E, Maksymiec W (1988) Characteristics of the photosynthetic apparatus of copper non-tolerant spinach exposed to excess copper. J Pl Physiol 132: 708-713

Bienfang PK (1980) Phytoplankton sinking rates in oligotrophic waters off Hawaii, USA. Mar Biol 61:69-77

Brand LE, Sunda WG, Guillard RRL (1983) Limitation of marine phytoplankton reproductive rates by zinc, manganese and iron. Limnol Oceanogr 28: 1182-1198

Brand LE, Sunda WG, Guillard RRL (1986) Reduction of marine phytoplankton reproduction rates by copper and cadmium. J exp mar Biol Ecol 96:225-250

Canterford GS, Canterford DR (1980) Toxicity of heavy metals to the marine diatom Ditylum brightwellii (West) Grunow: correlation between toxicity and metal speciation. J mar biol Ass UK 60: $227-242$

Cha JS, Cooksey DA (1993) Copper hypersensitivity and uptake in Pseudomonas syringae containing cloned components of the copper resistance operon. Appl envirl Microbiol 59: 1671-1674

Chongpraditnun P, Mori S, Chino M (1992) Excess copper induces a cytosolic $\mathrm{Cu}, \mathrm{Zn}$-superoxide dismutase in soybean root. PI Cell Physiol 33: 239-244

De Vos CHR, Schat H, Vooijs R, Ernst WHO (1989) Copper induced damage to the permeability barrier in roots of Silene cucubalis. J Pl Physiol 135: 164-169

De Vos CHR, Schat H (1991) Free radicals and heavy metal tolerance. In: Rozema J, Verkleij JAC (eds) Ecological responses to environmental stresses. Kluwer Acad Publ, Dordrecht, Netherlands, pp 22-30

De Vos CHR, Vonk MJ, Vooijs R, Schat H (1992) Glutathione depletion due to copper induced phytochelatin synthesis causes oxidative stress in Silene cucubalis. P1 Physiol 98: 853-858

Drebes G (1977) Sexuality. In: Werner D (ed) The biology of diatoms. Blackwell Sci Publ, Oxford, UK, pp 250-283

Fisher NS, Jones GJ, Nelson DM (1981) Effects of copper and zinc on growth, morphology, and metabolism of Asterionella japonica (Cleve). J exp mar Biol Ecol 51:37-56

Foster PL (1977) Copper exclusion as a mechanism of heavy metal tolerance in a green alga. Nature, Lond 269:322-323

Floyd RA, Watson JJ, Wong PK, Altmiller DH, Rickard RC (1986) Hydroxyl free radical adduct of deoxyguanosine: sensitive detection and mechanisms of formation. Free Rad Res Comms 1: $163-172$

French MS, Evans LV (1988) The effects of copper and zinc on growth of the fouling diatoms Amphora and Amphiprora. Biofouling $1: 3-18$

Gekeler W, Grill E, Winnacker E, Zenk MH (1988) Algae sequester heavy metals via synthesis of phytochelatin complexes. Arch Microbiol 150: 197-202

Gerringa LJA, Poortvliet TCW, Rijstenbil JW, Schot MC, Van Drie $J$ (1994) Speciation of copper in cultures of the marine diatom Ditylum brightwellii. Aquat Toxic (in press)

Gieskes WWC, Kraay GW (1983) Dominance of Cryptophyceae during the phytoplankton spring bloom in the central North Sea detected by HPLC analysis of pigments. Mar Biol 75: 179-185

Härdstedt-Roméo M, Gnassia-Barelli M (1980) Effect of complexation by natural phytoplankton exudates on the accumulation of cadmium and copper by the haptophyceae Cricosphaera elongata. Mar Biol 59:79-84

Hudson RJM, Morel FMM (1993) Trace metal transport by marine microorganisms: implications of metal coordination kinetics. Deep-Sea Res 40: 129-150

Kosakowska A, Falkowski L, Lewandowska J (1988) Effect of amino acids on the toxicity of heavy metals to phytoplankton. Bull envir Contam Toxic 40:532-538

Lee FJ, Hassan HM (1985) Biosynthesis of superoxide dismutase in Saccharomyces cerevisiae: effects of paraquat and copper. J Free Rad Biol Med 1:319-325 
Lee M, Li CW (1992) The origin of the silica deposition vessel of diatoms. Bot Bull Acad Sin 33:317-325

Lewis W (1984) The diatom sex clock and its evolutionary significance. Am Nat 123:73-80

McCord JM, Fridovich I (1969) Superoxide dismutase, an enzymatic function for erythrocuprein (hemocuprein). J biol Chem 244 6049-6055

Miller DM, Buettner GR, Aust SD (1990) Transition metals as catalysts of "autoxidation" reactions. Free Rad Biol Med 8: 95-108

Milne L, Nicotera P, Orrenius S, Burkitt M (1993) Effects of glutathione and chelating agents on copper-mediated DNA-oxidation: pro-oxidant and antioxidant properties of glutathione. Archs Biochem Biophys 304: 102-109

Mishra U, Kashyap AK, Pandey J (1993) Effects of copper on photopigments and photosystem II activity of cyanophage N-1 resistant mutant. Envir Technol 14:373-378

Morel FMM, Rueter JG, Anderson DM, Guillard RRL (1979) AQUIL: a chemically defined phytoplankton culture medium for trace metal studies. J Phycol 15:135-141

Reed RH, Gadd GM (1990) Metal tolerance in eukaryotic and prokaryotic algae. In: Shaw AJ (ed) Heavy metal tolerance in plants: evolutionary aspects. CRC Press Inc, Boca Raton, USA, pp $105-118$

Rijstenbil JW, Wijnholds JA (1991) Copper toxicity and adaptation in the marine diatom Ditylum brightwellii. Comp Biochem Physiol $100 \mathrm{C}: 147-150$

Rijstenbil JW, Poortvliet TCW (1992) Copper and zinc in estuarine water: chemical speciation and bioavailability to the marine planktonic diatom Ditylum brightwellii. Envir Toxic Chem 11: $1615-1625$

Rijstenbil JW, Mur LR, Wijnholds JA, Sinke JJ (1989) Impact of a temporal salinity decrease on growth and nitrogen metabolism of the marine diatom Skeletonema costatum in continuous cultures. Mar Biol 101: 121-129

Rijstenbil JW, Bakker C, Jackson RH, Merks AGA, De Visscher PRM (1993) Spatial and temporal variation in community composition and photosynthetic characteristics of phytoplankton in the upper Westerschelde estuary (Belgium, SW-Netherlands). Hydrobiologia 269/270:263-274

Rijstenbil JW, Sandee A, Van Drie J, Wijnholds JA (1994) Interaction of toxic trace metals and mechanisms of detoxification in the planktonic diatoms Ditylum brightwellii and Thalassiosira pseudonana. FEMS Microb Rev (in press)

Salin ML (1987) Toxic oxygen species and protective systems of the chloroplast. Physiologia Pl 72:681-689

Sandmann G, Böger P (1980) Copper deficiency and toxicity in Scenedesmus. Z PflPhysiol 98:53-59

Sokal RR, Rohlf FJ (1981) Biometry. The principles and practice of statistics in biological research, 2 nd Edn. W. H. Freeman and Co, New York

Stauber JL, Florence TM (1987) Mechanisms of toxicity of ionic copper and copper complexes to algae. Mar Biol 94:511 - 519

Stauber JL, Jeffrey SW (1988) Photosynthetic pigments in fifty-one species of marine diatoms. J Phycol 24: 158-172

Stauber JL, Florence TM (1990) Mechanism of toxicity of zinc to the marine diatom Nitzschia closterium. Mar Biol 105:519-524

Stegeman JJ, Brouwer M, Di Giulio RT, Förlin L, Fowler BA, Sanders BM, Van Veld PA (1992) Molecular responses to environmental contamination: enzyme and protein systems as indicators of chemical exposure and effect. In: Huggett RJ, Kimerle RA, Mehrle PM, Bergman HL (eds) Biomarkers: biochemical, physiological and histological markers of anthropogenic stress. Lewis Publ, Chelsea, USA, pp 235-335

Twiss MR, Welbourn PM, Schwärtzel E (1993) Laboratory selection for copper tolerance in Scenedesmus acutus (Chlorophyceaea). Can J Bot 71:333-338

Van Assche F, Clijsters H (1990) Effects of heavy metals on enzyme activity of plants. Plant Cell Envir 13: 195-206

Verweij W, Glazewski R, De Haan H (1992) Speciation of copper in relation to its bioavailability. Chem Spec Bioavail 4: 43-51

Voloudakis AE, Bender CL, Cooksey DA (1993) Similarity between copper resistance genes from Xanthomonas campestris and Pseudomonas syringae. Appl envirl Microbiol 59: 1627-1634

Waite A, Harrison PJ (1992) Role of sinking and ascent during sexual reproduction in the marine diatom Ditylum brightwellii. Mar Ecol Prog Ser 87: 113-122

Wikfors GH, Neeman A, Jackson PJ (1991) Cadmium-binding polypeptides in microalgal strains with laboratory-induced cadmium tolerance. Mar Ecol Prog Ser 79: 163-170

Wingate VP, Lawton MA, Lamb CJ (1988) Glutathione causes a massive and selective induction of plant defense genes. Pl Physiol $87: 206-210$ 